\title{
Tourists Perceptions and Satisfaction Regarding Tour Guiding in the Republic of North Macedonia
}

\author{
Kliment Naumov \\ PhD, University of "St. KLiment Ohridski"-Bitola, Faculty of tourism and hospitality-Ohrid, \\ Republic of North Macedonia
}

\begin{abstract}
Tourism is diverse industry and therefore it involves many different stakeholders for it operational activities. An essential element for sustainable tourism development in any tourist destination is the participation of active stakeholders and the cooperation between them. Among all, the tour guides play a major role in the tourism industry since tourists need to have a clear picture of the country and its offer, laws, rules and regulations and other expected behavioral patterns. Moreover, guides should have the ability to transform the tourist visit into an unforgettable experience. In addition to the quality and ability of tourist guides, there are many problems and issues associated with their services that can impact the ultimate satisfaction of tourists. In the Republic of North Macedonia, there is a positive trend in tourist guiding in the last 20 years. It is because of this fact that this paper pays attention to the role and importance of tour guiding for the Macedonian tourism.
\end{abstract}

Keywords: tourism, tourist destination, tourist experience, tour guides, tour guiding, empirical research

\section{Introduction}

The role of the modern tour guide has its direct historical origins from the Great Tour of the 17th and 18th centuries (Brodski-Porges 1981; Hilbert 1969: Lambert 1935) and in the beginnings of modern tourism, which eventually replaced the Grand Tour in 19th century. Its predecessors, however, are numerous and diverse and reach far into mythology, allegorical literature, history and geographical research. In order to understand the structure and dynamics of the role of the modern tourist guide, these predecessors should be examined, because they have set the cultural background due to which its modern role has developed. (Cohen, 1985)

For all its apparent simplicity, "guiding" is a complex concept: and while there are many different types of guiding, some of this complexity also marks the tourist guide. A good start to appreciate that complexity can be made by considering an authoritative dictionary definition of the term: the Oxford English Dictionary defines the concept "guide" as "One who leads or shows the way especially to a traveller in a strange country; spec. one who is hired to conduct a traveller or tourist (e.g., over a mountain, through a forest or over a city or building) and to point out objects of interest" (Oxford 1933:IV/490)

Tour guides' main job function is to guide and bring the tourists with wonderful travelling experiences. They effectively submerse the tourists within the sightseeing spots thoughtfully. 
Therefore, in order to guide tourists to the pleasant journey, they should have some professional techniques. In addition, regarding the dimension of their professional attitude, it means the drive of affection and it is a person's behavioral performance and the learning related to attitude and affection. It is the attitude or value required when tour guides guide or work on tourists' travel business. Positive professional attitude is the key factor for excellent tour guides to successfully guide the tour groups (Curtin, 2010; Green \& Jones, 2010).

Tour guides act as ambassadors of the country, they are the first to meet and greet tourists and they are often the last to say goodbye to them when they leave the country.

Tourism is a communication phenomenon; the best promoter of the tourist destination is the tourist who is satisfied with the visit. If the visitor is misunderstood by the community at the place he or she visits or by the professionals who accompany him/her, even if the tourist visits the most beautiful place in the world, he or she will be left with a negative opinion which is bad propaganda (Jonasson, 2014). This is where the role of the tour guide comes into play. It must be a versatile person, with the skills of a psychologist able to anticipate the needs of the clients, as well as to correctly interpret the phenomena and relationships in the tourist destination.

An empirical research was presented on the prepared research on the perceptions and selfperceptions of the tourist guides in the Republic of Macedonia as the first part and the research, with a provided research sample of 50 tourist guides for which structured interviews were prepared. The focus was set on the profession, using the method of observation, inventoried them in terms of experience and knowledge of foreign languages. For the research regarding the perceptions and satisfaction of the clients from the tour guiding in the Republic of Macedonia, a representative research sample of 1500 tourists was provided which were examined within three tourist seasons starting from 2017 and ending by 2019. A total of 1152 survey questionnaires were fully completed and processed.

Empirical research on the perceptions and satisfaction of the clients from the tour guiding in the Republic of North Macedonia

The survey method was followed by examining the attitudes of foreign tourists towards local tourist guides. The research was part of the doctoral thesys with the topic: Role and significance of tour guiding for the tourism in the Republic of Macedonia, defended on the 20th of July 2020 at the University"St. Kliment Ohridski"-Bitola, Faculty of tourism and hospitalityOhrid, Republic of North Macedonia, in original: "Улога и значење на туристичкото водење за туризмот во Република Македонија". The questionnaire was intended for customers (tourists) whose purpose was to determine "consumer behavior when consuming or using a product or service" (Vukonic, Cavlek, 2001: 20), ie to get a comprehensive impression of perceptions and experiences of service users. Having in mind the fact that the organized tourist flow in Ohrid, Republic of North Macedonia is starting to be more stable and less spontaneous, it was possible to contact tourists from all profiles, but we chose the ones that are already present, and who if not the Dutch visitors. The Dutch and Poles are one of the most present tourists in the Republic of North Macedonia, with the most overnight stays per tourist (around 5.7). They come with charter flights directly to Ohrid, but there is also a significant number that arrive as part of larger Balkan tours conducted by coaches. Both kinds of groups were taken into account during the research. Most of the groups carry out at least one to two 
activities, such as a tour of the old town of Ohrid and a visit to the monastery of St. Naum in combination with the Galicica National park.

The research sample was taken from the population of Dutch, Polish, Chinese, Japanese, Malaysian, Vietnamese, Korean, and tourists from Singapore, Hong Kong, Taiwan, as well as a number of tourists from the United States, Canada, Australia, South Africa and the United Kingdom. They were users of the services of several well-known tour operators in the world and in Europe: Kuoni - Hong Kong, China, Bolderman and TUI from the Netherlands. Kuoni is one of the oldest European tour operators originating in Switzerland with a huge number of branches worldwide. One of them is the company located in the emissive zone of Hong Kong. Tour operator Bolderman specializes in roundabout bus tours for "third age" customers. While TUI provides services to clients who are of mixed age groups, but still predominate users of services belonging to the age group of 50 years and above.

The research was agreed with the following tour operators: the travel agency Compass from Rotterdam. Compass is an agent who organizes on behalf of Bolderman. The owner, as well as the general manager Andrej Zupancic, enthusiastically accepted the request for a survey and asked for the results after its realization. Thus, an agreement was reached to conduct a survey of 8 groups of Dutch tourists who have the program "Byzantine Cities" which includes all former Yugoslav republics along with Albania, not including Greece. The research sample when it comes to Dutch tourists is quite unique because of the 242 tourists covered in this research, 200 were guided by the same guide in their own language, while the remaining 42 were guided by different guides during their entire stay.

The tourists were asked to keep the questionnaires and at the end of the third day of their four-day stay to return them filled in to the agency representative-driver. All distributed surveys were completed because there was enough time for that. All completed questionnaires were collected during the morning hours of the fourth day of the guests' stay.

Albania Experience / Landways, one of the leading destination management organizations in Southeast Europe, working with tour operators in the Far East, has responded to a survey request. Thanks to owner Gazmend Hahxia and CEO Neritan Selita, the survey was successfully conducted and included 267 respondents: 10 from China, 77 from Japan, 52 from Malaysia, 20 from Indonesia, 20 from Vietnam, 20 from Taiwan38, Hong Kong 11, Singapore 3 and South Korea 56.

The Americans and some of the tourists from the Commonwealth countries were covered through individual tours organized by the American tour operator Jay Way. It was a total of 46 visitors, including 24 tourists from the United States, 10 tourists from New Zealand, 10 tourists from Australia and 2 tourists from Canada who as individual tourists or in groups of a maximum of four were on a Balkan tour in which Ohrid was an integral part. The tours were combined with the monastery of St. Naum and the Galicica National Park, and visit of the capital city Skopje in combination with Matka.

Through the British tour operator VJV Voyages Jules Verne were surveyed 80 tourists from the UK who, like the aforementioned respondents, were on a one-week tour including Kosovo, Macedonia and Albania, having two overnight stays in our country, one in Skopje and one in Ohrid. The Macedonian part of the program included the Matka canyon with the Vrelo cave, a visit to Skopje on the first day and a visit to the ancient city of Stobi with wine tasting in Demir Kapija and accommodation in Ohrid on the second day. On the third day they had a sightseeing 
of the old city of Ohrid, lunch and departure for Albania. Specific for this research sample is that 2 guides were changed, one of which led 6 groups while the other 2 groups.

The Danish-Bulgarian tour operator Penguin Travel specializes in round-the-world tours. One of its features is that it serves customers from all over the world and on a tour together it can happen that literally tourists from China, India, USA, Netherlands, Great Britain, Ireland, Brazil, Australia, New Zealand, South Africa, Canada, Georgia, Malaysia etc. Through this tour operator were surveyed 127 respondents, of which 48 were from the United States, 5 from Canada, 11 from Australia, 14 from New Zealand, 11 respondents from South Africa, 5 from China, 6 from Ireland, 7 from Brazil, 5 from India. , 6 from Georgia and 9 from Malaysia.

The Polish tourists in this study are the second largest research sample after the Dutch visitors with 198 respondents. In their case, the examination was conducted during the boat tours to St. Nahum during the 4 consecutive months, at the end of May, the end of June, the middle of July and the middle of August. Most of them, 3 groups were led by a tour guide whose mother tongue was Polish, while 1 group was led by a tour guide who speaks Polish, but not as a native speaker.

The other respondents from several countries should be mentioned, including the area of the surrounding region. They were examined through the association of tourist guides and companions Kej from Ohrid at several locations in the old part of the city of Ohrid, while they had a break during their tour of the old town. This is a case of Bulgarian, Serbian, Montenegrin, Croatian, Albanian, Kosovo and Greek visitors, led by unknown local tour guides. But it also includes tourists from Israel, Slovakia, Spain, Norway, Denmark, Lithuania, Hungary, Germany, Estonia, Ukraine, Egypt, France, Italy and Romania.

\section{Methodology}

The survey questionnaire was based, in part, on the McDonnell (2001) Tourist Satisfaction Survey. Regarding the Australian questionnaire, the question of satisfaction with the presentation of the tour guide was adjusted in terms of the specific elements that were subject to evaluation, and two new questions were included: one in order to determine what is the main concern of tourists in terms of local tours, and secondly to get the opinion of tourists about the most important role of tourist guides. The questionnaire also contains general data on the respondents, ie their socio-demographic characteristics: age, gender, level of education and country of permanent residence. The empirical part of the paper covers fieldwork. Systematic observation was used to collect primary data from empirical analysis, and more specific techniques were interviewing and surveying. The research, refering to the perceptions and satisfaction of the clients from the tour guiding in the Republic of Macedonia, was conducted by applying the technique of surveying the visitors. The time interval of research activities (cabinet and field) started in 2017, but mostly refers to the tourist season in 2018 with a certain extension in 2019. The survey questionnaire covered 1,500 respondents, with 1152 fully completed surveys. The questionnaire assessed the various contents through the

Likert scale. The results obtained are sublimated in tabular reviews through an average score and standard deviation.

\section{Statistical processing}

Descriptive statistics techniques were used for data processing, which includes calculation of frequency and percentage, calculation of the arithmetic mean and standard deviation of the 
given answers. The meaning of the differences in the arithmetic means was also checked. Univariate analysis of variance (ANOVA) tested the significance of the difference between arithmetic means (derived from dependent variables) between subcategories of each of the independent variables (F coefficient). Regression and correlation analysis were also applied in order to establish the existence and nature of the relationship between the individual variables. In this paper, the correlation is expressed using the Pearson correlation coefficient. The value of this coefficient can theoretically range from +1 (perfect positive correlation) to 1 (perfectly negative correlation). The sign of the coefficient indicates the direction of correlation, ie. whether it is positive or negative, but does not show the strength of the correlation. Pearson correlation coefficient is based on comparing the true impact of one variable on another, in terms of the maximum possible impact. Regression analysis is a method that examines and determines the dependence between two or more variables, ie. the influence of the change of one or more variables on the change of the other variables is perceived. At stake is the study of the cause-and-effect relationship and the validity of predicting the value of one variable based on knowledge of the value of others. The data from the questionnaires were processed using the computer program SPSS (Statistical Package for the Social Sciences) version 19.0.

\section{Characteristics of the Research Sample}

The total number of processed questionnaires was 1152 and it is important to note that the answers were received from the respondents to all questions. Therefore in all questions there is no difference in the sum of answers. The characteristics of the sample are given in the following table.

Table 1 by author Characteristics of the research sample(by author)

\begin{tabular}{|c|c|c|c|}
\hline \multicolumn{2}{|c|}{ Variable } & \multicolumn{2}{c|}{ Characteristics of the research sample } \\
\cline { 2 - 4 } & & Frequency & Percentage \% \\
\hline \multirow{3}{*}{ gender } & male & 517 & 45.0 \\
\cline { 2 - 4 } & female & 634 & 55,0 \\
\hline \multirow{3}{*}{ age } & Under 18 & 66 & 5.7 \\
\cline { 2 - 4 } & $18-28$ & 152 & 13.2 \\
\cline { 2 - 4 } & $29-39$ & 213 & 18.5 \\
\cline { 2 - 4 } & $40-49$ & 67 & 5.8 \\
\cline { 2 - 4 } & $50-60$ & 187 & 16.2 \\
\cline { 2 - 4 } & $61+$ & 467 & 20.5 \\
\hline \multirow{4}{*}{ Educational level } & High school & 240 & 49.4 \\
\cline { 2 - 4 } & College & 569 & 27.9 \\
\cline { 2 - 4 } & University & 321 & 1.9 \\
\cline { 2 - 4 } & Post graduate degree & 22 & 0.8 \\
\cline { 2 - 4 } & & & 0 \\
\hline
\end{tabular}

Men make up $44.9 \%$ of the research sample, while women make up 55.1\%. Out of the total number of respondents, $94.5 \%$ belong to the age category over 50 years. In fact, $16.2 \%$ belong to the age category of 50 to 60 years, while $40.5 \%$ of the respondents belong to the age group of 61 years and above. Only $5.8 \%$ belong to the age group between 40 and 49 years. 18.5\% belong to the age group between 29 and 39 years. In the age category between 18 and 28 years 
belong $13 \%$ and under 18 years $5.7 \%$. It can be said that $56.7 \%$ belong to the third age group, ie. predominantly tourists who are mostly retired or before retirement.

Regarding the level of education, relatively normal results were obtained. Of all respondents, $20.18 \%$ have completed secondary education, just over $49 \%$ have completed high school or as it is popularly called college, $27.9 \%$ have a university degree and $1.9 \%$ have a postg graduate education degree. In contrast to a 2001 study by Med Donell in Australia, which found surprising results in terms of education, with the majority of respondents not being honest about their education and stating that they had a bachelor's or doctorate, our research resulted in completely realistic and expected results. They all stated in which country they have a permanent place of residence. Most of the respondents come from the Kingdom of the Netherlands with $21.7 \%$, followed by Poland with $17.2 \%$, followed by the United Kingdom with $6.9 \%$, Japan with 6.7\%, both Malaysia and South Korea with 4.9\%, Taiwan with 3.9\%, Hong Kong with 1\%, New Zealand with 1.5\%, and Australia with $1.6 \%$. It can be concluded that European tourists predominate, while visitors from East Asia and the Pacific are also present in a good percentage.

\section{Results and discussion}

The answer to the first question should indicate what is the main concern of the tourists in relation to the local tours in the destination, ie which aspect of the tour they take into account when deciding on it. As can be seen from Table 1, two main and dominant concerns of tourists is the "Presentation of the tourist guide" (59.5\%) and the "program and itinerary" (22.9\%). Other aspects of the tours offered as a possible answer ("walking and attraction attractions", "price" and "weather conditions") are presented in a significantly lower percentage, and "vehicle quality" was rounded out by only 15 respondents or $1,3 \%$.

It can be concluded that for tourists two aspects of the tour are obviously the most important. The competence of the tour guide (presentation skills) and the quality of the information that would be obtained from him/her, as well as the program of the tour, ie. the attractions they would visit or see are the main concerns of thetourists in Macedonia.

Table 2 Main concerns of the tourists in relation to the local tours in the destination (by author)

\begin{tabular}{|c|c|c|}
\hline & Frequency & Percentage \% \\
\hline Program and itinerary & 264 & 22,9 \\
\hline Presentation of the tourist guide & 685 & 59,5 \\
\hline Duration & 35 & 3,0 \\
\hline Accessibility of points & 19 & 1,6 \\
\hline Vehicle quality & 15 & 1,3 \\
\hline Other & 23 & 2,0 \\
\hline Price & 58 & 5,0 \\
\hline Weather conditions & 52 & 4,5 \\
\hline Total & 1152 & $100 \%$ \\
\hline
\end{tabular}

If we take into account the data from the previous table, it is natural that most $34.9 \%$ of tourists think that the main role of the tour guide is to be an information provider and educator as shown in the table below. Immediately after that is the opinion that the tourist guide should 
be an ambassador, PR and protector of his destination. We live in a time when great attention is paid worldwide to the preservation of the environment and the cultural and natural heritage. Of course the tour guide must be a reminder and give an example of how tourists and other visitors should behave in the destination, especially in protected areas. Such a result is in line with the general picture of the role of local tour guides in the destination. A relatively large number of respondents believe that the main role of the tour guide is to be a "cultural mediator" (15.7\%). Communicating with people from the destination further enriches the experience and intensifies the memories that visitors would have after going back home. Of course, the tour guide should also be a "leader and organizer" (13.5\%). The most precious asset for every person is the time. The guide must be careful and well organized so that he or she does not waste one's clients' time. To be able to achieve this one must have leadership skills and enjoy a certain level of authority from clients' perspective. The role of interpreter and translator should not be neglected (8.9\%), which is the basic role of the guide. If this role is excluded, the whole system of tour guiding would fall apart. The smallest number of respondents opted for the option of companion and guardian of tourists $(3.6 \%)$. This can be understood from two aspects: Macedonia in the eyes of visitors is a country with a high degree of security and tourists do not feel fear during their stay; or the local tourist guide is indeed in some of his responsibilities and tasks both a companion and a guardian, but due to the fact that most of the respondents entered Macedonia together with their tour guide and in this case exclude that role with the local guide. Respondents were able to complete only one of the offered answers, which probably influenced their choice for a standard and generally known role. Such a choice, however, does not mean denying the importance of other roles, especially when they are intertwined in practice: from the point of view of foreign tourists, providing information is not just a list of facts, but revealing information tailored to the interests and cultural background of service users.

Table 3 Main role of local tour guide (by author)

\begin{tabular}{|c|c|c|}
\hline & Frequency & Percentage \% \\
\hline Informator and educator & 402 & 34.9 \\
\hline Interpreter and translator & 102 & 8.9 \\
\hline Cultural mediator & 181 & 15.7 \\
\hline Leader and organiser & 155 & 13.5 \\
\hline $\begin{array}{c}\text { Companion and gurdian } \\
\text { Ambassador, PR and protector of the } \\
\text { destionation }\end{array}$ & 42 & 3,6 \\
\hline Total & 270 & 23.4 \\
\hline
\end{tabular}

Regarding the assessment of the quality of the tours in which they participated (sightseeing of Skopje, Ohrid and St. Naum), the respondents managed to achieve a scale from 1 to 10 . As can be seen from the table below, almost $80 \%$ of the respondents believe that the quality of the tours exceeded their expectations and is more than satisfactory, about $20 \%$ consider it satisfactory and less than $1 \%$ considers the quality of the tours to be unsatisfactory. The average score is 8.9 , which can be interpreted as an excellent grade.

Table 4 Tours quality assessment (by author)

\begin{tabular}{|c|c|c|}
\hline & Frequency & Percentage \% \\
\hline More than satisfying (rate 9-10) & 836 & 72,5 \\
\hline
\end{tabular}




\begin{tabular}{|c|c|c|}
\hline Satisfying (rate 6-8) & 267 & 23.1 \\
\hline Unsatisfying (rate 1-5) & 47 & 0,4 \\
\hline Total & 1152 & 100 \\
\hline Average rating & \multicolumn{2}{|c|}{8,88} \\
\hline
\end{tabular}

It is indicative that individuals needed, at the end of the highest grade, to supplement with a comment ("excellent", "living encyclopedia", "thanks for the stories and anecdotes", "has a good sense of humor", etc.), which testifies for their extraordinary pleasure. Very few tourists rated the quality of the tours as low. Interestingly, such questionnaires also recorded specific reasons for dissatisfaction ("the guide was often unclear in his statements", "the guide started telling the story in our absence, we moved slowly because of my arthritis", "our guide he wore sunglasses while addressing us and I consider that extremely rude ").

The data processing also checked whether the average assessment of the quality of the tours differs between the respondents with different demographic characteristics. It turned out that there is a statistically significant difference in relation to the permanent place of residence of the respondents. This difference is statistically significant at the level of 0.05 , which means that with $95 \%$ certainty it can be argued that the differences obtained in this sample really exist in the populations of tourists from different emission zones worldwide.

Dutch tourists are most satisfied with the fluency of the tour guide. 93.2 of the respondents who were guided in Dutch rated the language skills of the guide with the highest score, while $6.8 \%$ rated the fluency of their guide as very good. It should be noted that 84.7 of the Dutch respondents had a guide in their mother tongue. The most dissatisfied with the language skills of the tour guide were the tourists from France who 100\% rated the fluency with an extremely negative grade. One hundred percent satisfaction when it comes to the language fluency of the tour guide can be noticed in the respondents from Ukraine, Slovenia, Belgium, Greece and Austria, but it is a small number of respondents that ranges up to less than one fifty tourists. In fact, these are respondents from the same group.

Namely, at first glance it can be seen that the grades given by the respondents from the Netherlands and Poland are higher than those who are not traditional visitors to Macedonia.

Table 5 Tour quality assessment according to country of arrival of tourists (by author)

\begin{tabular}{|c|c|c|c|c|c|c|}
\hline & \multicolumn{5}{|c|}{ Crossing of 2 variables: Country of origin and tour quality } \\
\cline { 2 - 7 } & \multicolumn{3}{|c|}{$\begin{array}{c}\text { Dependent variable: On scale from 1 to 10 where 10 is excellent and 1 is very bad, } \\
\text { how would you rate the quality of your tour in Macedonia? }\end{array}$} \\
\hline Countries & $\begin{array}{c}\text { Nominal } \\
\text { number of } \\
\text { respondents }\end{array}$ & $\begin{array}{c}\text { Percentage } \\
\text { of the total } \\
\text { number }\end{array}$ & grade & Standard mistake & \multicolumn{2}{c|}{$\begin{array}{c}95 \% \text { interval of } \\
\text { credibility }\end{array}$} \\
\cline { 4 - 7 } & 3 &, 3 & 9,000 &, 811 & 7,410 & $\begin{array}{c}\text { Lowest grade } \\
\text { grade }\end{array}$ \\
\hline Albania & 3 &, 7 & 9,500 &, 496 & 8,526 & 10,590 \\
\hline Argentina & 8 & 1,6 & 7,833 &, 331 & 7,184 & 8,483 \\
\hline Australia & 18 &, 7 & 9,500 &, 496 & 8,526 & 10,474 \\
\hline Austria & 8 &, 1 & 10,000 & 1,404 & 7,245 & 12,755 \\
\hline Bahrein & 1 &, 3 & 9,333 &, 811 & 7,743 & 10,924 \\
\hline Belgium & 3 &, 4 & 7,200 &, 628 & 5,968 & 8,432 \\
\hline Brasil & 5 & & & &
\end{tabular}




\begin{tabular}{|c|c|c|c|c|c|c|}
\hline Bulgaria & 15 & 1,3 & 8,200 & ,362 & 7,489 & 8,911 \\
\hline Canada & 4 & ,3 & 9,500 & ,702 & 8,123 & 10,877 \\
\hline PRC & 14 & 1,2 & 9,571 & ,375 & 8,835 & 10,308 \\
\hline Croatia & 11 & 1,0 & 8,545 & ,423 & 7,715 & 9,376 \\
\hline Danemark & 13 & 1,1 & 9,385 & ,389 & 8,621 & 10,149 \\
\hline Egypt & 1 & ,1 & 9,000 & 1,404 & 6,245 & 11,755 \\
\hline Estonia & 7 & 6 & 9,000 &, 531 & 7,959 & 10,041 \\
\hline Finland & 13 & 1,1 & 9,000 & ,389 & 8,236 & 9,764 \\
\hline France & 3 & ,3 & 7,333 & 811 & 5,743 & 8,924 \\
\hline Georgia & 6 &, 5 & 8,500 &, 573 & 7,375 & 9,625 \\
\hline Germany & 11 & 1,0 & 8,818 & ,423 & 7,988 & 9,649 \\
\hline $\begin{array}{c}\text { Great } \\
\text { Britain }\end{array}$ & 80 & 6,9 & 8,725 & ,157 & 8,417 & 9,033 \\
\hline Greece & 4 & ,3 & 9,500 & ,702 & 8,123 & 10,877 \\
\hline Hong Kong & 11 & 1,0 & 10,000 & ,423 & 9,169 & 10,831 \\
\hline Hungary & 4 & ,3 & 10,000 & ,702 & 8,623 & 11,377 \\
\hline India & 5 & ,4 & 8,600 & ,628 & 7,368 & 9,832 \\
\hline Indonesia & 20 & 1,7 & 10,000 & ,314 & 9,384 & 10,616 \\
\hline Ireland & 5 &, 4 & 7,000 & ,628 & 5,768 & 8,232 \\
\hline Israel & 8 & ,7 & 8,875 & ,496 & 7,901 & 9,849 \\
\hline Italy & 4 &, 3 & 8,000 & ,702 & 6,623 & 9,377 \\
\hline Japan & 77 & 6,7 & 8,714 & ,160 & 8,400 & 9,028 \\
\hline Kosovo & 1 & 1 & 10,000 & 1,404 & 7,245 & 12,755 \\
\hline Lithuania & 3 & 3 & 10,000 & ,811 & 8,410 & 11,590 \\
\hline Macedonia & 1 & ,1 & 9,000 & 1,404 & 6,245 & 11,755 \\
\hline Malaysia & 56 & 4,9 & 9,286 & ,188 & 8,918 & 9,654 \\
\hline $\begin{array}{l}\text { Monte } \\
\text { Negro }\end{array}$ & 3 & 3 & 8,333 & ,811 & 6,743 & 9,924 \\
\hline Netherlands & 242 & 21,0 & 9,153 & ,090 & 8,976 & 9,330 \\
\hline $\begin{array}{c}\text { New } \\
\text { Zealand }\end{array}$ & 17 & 1,5 & 8,706 & ,340 & 8,038 & 9,374 \\
\hline Norway & 9 & 8 & 8,667 & ,468 & 7,748 & 9,585 \\
\hline Pakistan & 7 &, 6 & 7,000 & ,531 & 5,959 & 8,041 \\
\hline Poland & 198 & 17,2 & 8,808 & , 100 & 8,612 & 9,004 \\
\hline Romania & 12 & 1,0 & 9,250 & ,405 & 8,455 & 10,045 \\
\hline Serbia & 22 & 1,9 & 9,273 & ,299 & 8,685 & 9,860 \\
\hline Singapur & 3 & ,3 & 9,333 & 811 & 7,743 & 10,924 \\
\hline Slovakia & 14 & 1,2 & 10,286 & ,375 & 9,550 & 11,022 \\
\hline Slovenia & 11 & 1,0 & 9,182 & ,423 & 8,351 & 10,012 \\
\hline South Africa & 11 & 1,0 & 8,455 & ,423 & 7,624 & 9,285 \\
\hline South Korea & 56 & 4,9 & 8,839 & 188 & 8,471 & 9,207 \\
\hline Spain & 1 & ,1 & 6,000 & 1,404 & 3,245 & 8,755 \\
\hline Sweden & 10 & ,9 & 9,500 & ,444 & 8,629 & 10,371 \\
\hline Taiwan & 38 & 3,3 & 8,079 & 228 & 7,632 & 8,526 \\
\hline Ukraine & 7 &, 6 & 7,857 &, 531 & 6,816 & 8,898 \\
\hline USA & 48 & 4,2 & 9,125 & 203 & 8,727 & 9,523 \\
\hline Vietnam & 20 & 1,7 & 8,100 & ,314 & 7,484 & 8,716 \\
\hline
\end{tabular}


The lowest scores were given by the respondents from Spain, Pakistan, Australia, Brazil, Ireland, France and Ukraine. The fact that the majority of this group of respondents comes from countries where tourism is at a much higher level than ours, they have a lower threshold of tolerance for deviations from their expectations. There is also a possibility that this is an expression of the "superlative" attitude of individuals, which certainly affected the level of ratings given for the tours. Their ratings are statistically significantly lower than the ratings of those respondents listed as traditional visitors to Macedonia, on It should be taken into account that the size of the research sample that critically addressed the quality of the tours in Macedonia is disproportionately small, but still important because it is a rounded group of respondents who in a certain place and at a certain time are Although every human being is a subjective being, when it comes to collective travel, subjective factors are excluded and objectivity comes to the fore.In the same group of critical respondents were visitors from Pakistan.Their dissatisfaction is based on the essence of the tourist offer in Macedonia, starting from the fact that Pakistan is an Islamic republic, when visiting a country like Macedonia, which is secular according to the social order, a small shock immediately occurs. The biggest reason why Pakistani visitors were not very happy with their visit to Macedonia is the fact that the program did not include Islamic cultural monuments. They visited only churches and not a single mosque. They were not given time to pray and so on. The determination of the statistical significance of the differences in the performed average grades was performed by analysis of variance (ANOVA).

Regarding the quality of the tours, it was interesting to find out which of the examined variables most influenced the level of grades. As can be seen from the table, the greatest influence on the evaluation of the quality of the tours have "ease of understanding the information" and "satisfaction with the received information", as well as the estimated ability of the respondents to explore the city after the tour with the guide. It can be concluded that the tour guides to a small extent tried harder in their attempts to encourage tourists to interact with the locals, than the level of the degree of total satisfaction with all the information together. The guide's attempts to encourage tourists to interact with the local environment and population inversely affect the overall satisfaction with all information.

Table 6. Influence of particular dependent variables to the general rating of the tours (by author)

\begin{tabular}{|c|c|c|c|c|c|}
\hline & & $\begin{array}{l}\text { Non standard } \\
\text { coeficients }\end{array}$ & $\begin{array}{c}\text { Standard } \\
\text { coeficients }\end{array}$ & & \\
\hline & B & $\begin{array}{l}\text { Standard } \\
\text { mistake }\end{array}$ & Beta & $\mathrm{t}$ & Sig. \\
\hline Satisfaction of all the information & 2,300 & ,063 & & 36,622 & ,000 \\
\hline $\begin{array}{l}\text { Was the presented information easy } \\
\text { to understand? }\end{array}$ & 326 & ,011 & ,595 & 29,471 & ,000 \\
\hline $\begin{array}{l}\text { How selfconfident are you in you } \\
\text { ability to explore the town on your } \\
\text { own after the end of the tour? }\end{array}$ & 203 & ,011 & 353 & 17,865 & , 000 \\
\hline $\begin{array}{l}\text { How effective were the guide's tryes } \\
\text { to encourage interaction with the } \\
\text { local population? }\end{array}$ & $-, 025)$ & ,011 & $-, 041)$ & $\begin{array}{c}- \\
2,195)\end{array}$ & ,028 \\
\hline
\end{tabular}

It can be concluded that the tourists gave particularly high marks. The overall rating for the tours ranges from 4.2 in terms of ease of understanding the information provided by the tour 
guide, 4.3 for the degree of confidence and ability to independently explore the site after the tour, 4.5 is the rating for the effectiveness of guide in encouraging interaction with the local environment the easier it was for them to understand the tour guide and the information presented, the more satisfied they were with the information during the tours, the more confident they felt to explore the places on their own. These three variables are good predictors for assessing the quality of tours at a significance level of 0.01 ( $99 \%$ certainty).

In addition to assessing the quality of the tours, respondents also assessed the impact of the tour guide on their own experience. The results shown in Table 7 confirm the importance that a tour guide can have for the tourist experience. Almost all respondents think that the influence of the guide is positive: $80.7 \%$ think that it is extremely positive, and $19.0 \%$ that it is positive. For only $2 \%$ of the respondents the impact of the tourist guide was negative. The average score of 4.7 shows that the impact was very positive. It is interesting that fewer negative ratings are given to tour guides than to the tours themselves.

Table 7. The importance of tour guide to the overall experience of the tourists (by author)

\begin{tabular}{|c|c|c|}
\hline & Frequency & Percentage \% \\
\hline Extremely positive 5 & 930 & 80,7 \\
\hline Positive 4 & 219 & 19.0 \\
\hline Neutral 3 & 2 & 0.2 \\
\hline Negative 2 & 1 & 0.1 \\
\hline Extremely negative 1 & 0 & 0.0 \\
\hline Average grade SD & \multicolumn{2}{|c|}{$4.7(0,5)$} \\
\hline
\end{tabular}

It is interesting that each result obtained for the overall satisfaction with the information varies statistically significantly in relation to the average value depending on the place of residence of the respondents. As with the assessment of the quality of the tours, the respondents coming from Poland, followed by the visitors from the Netherlands, who gave higher grades, ie were satisfied with the information received from their guide, while respondents from Asian countries gave lower grades. In order to determine which type of information significantly affected the overall satisfaction with the information provided by the guide, a linear regression analysis procedure was performed which revealed that information about modern life and current events, Macedonian customs and local rules, as and shopping and leisure activities are information that significantly affected the overall satisfaction of tourists with the information received (Table 8). Given that the results obtained from the mean values of satisfaction with the information received in terms of history and geography are greater than the score obtained from the total satisfaction, and the satisfaction results of other types of information are lower compared to the sitting score of total satisfaction of all information and since this is information that took the last places according to the average satisfaction scores, it would be good for tour guides to pay more attention to aspects of orientation, Macedonian customs and shopping and leisure activities when informing tourists. It can be concluded that the tourist guides did their best to capture the Macedonian tradition and customs for their clients, as well as to spend a little more of their free time to fill the free time of the tourists. Tour guides often consider their clients' free time as their own free time and do not pay an adequate level of attention to tourists if they request a service during that 
period. Guides often forget that they are paid to deliver a full service, which lasts until they see the group off.

Table 8. Influence of certain types of information in the overall satisfaction of the received (by author)

\begin{tabular}{|c|c|c|c|c|c|}
\hline & \multicolumn{2}{|c|}{$\begin{array}{c}\text { Non standardized } \\
\text { coefficients }\end{array}$} & \multirow{2}{*}{$\begin{array}{c}\text { Standardized coefficients } \\
\text { Beta }\end{array}$} & \multirow[t]{2}{*}{$\mathrm{T}$} & \multirow[t]{2}{*}{ Sig. } \\
\hline & B & $\begin{array}{c}\text { Statistical } \\
\text { mistake }\end{array}$ & & & \\
\hline History & 0.143 & 0.000 & 0.261 & 1,91 & 0.00 \\
\hline Geography & 0.143 & 0.00 & 0.238 & 1,77 & 0.00 \\
\hline Modern life and actualities & 0.143 & 0,000 & 0,211 & 1,73 & 0,00 \\
\hline Customs & 0.143 & 0,000 & 0,242 & 1,85 & 0,00 \\
\hline Shopping and leisure time & 0.143 & 0,000 & 0,261 & 1,24 & 0,00 \\
\hline Special places & 0.143 & 0,000 & 0,223 & 1,78 & 0,00 \\
\hline Orientation & 0.143 & 0,000 & 0,251 & 1,24 & 0,00 \\
\hline
\end{tabular}

Table 9. Correlation (by author)

\begin{tabular}{|c|c|c|c|c|c|c|c|c|c|c|}
\hline \multicolumn{2}{|c|}{} & $\begin{array}{c}\text { Qual } \\
\text { ity } \\
\text { of } \\
\text { stay }\end{array}$ \\
\end{tabular}




\begin{tabular}{|c|c|c|c|c|c|c|c|c|c|c|}
\hline \multirow[t]{2}{*}{ Contemporary life } & $\begin{array}{c}\text { Pearso } \\
n \\
\text { Correl } \\
\text { ation }\end{array}$ & ,242 & ${ }_{*}^{161}$ &, $188^{* *}$ & 1 & $188^{*}$ &, $155^{* *}$ & , 175 &, $112^{* *}$ & $451^{*+}$ \\
\hline & $\begin{array}{l}\text { Sig. (2- } \\
\text { tailed) }\end{array}$ & 000 &, 000 & ,000 & & , 000 & , 000 &, 000 & ,000 & 000 \\
\hline \multirow[t]{2}{*}{ Customs } & $\begin{array}{c}\text { Pearso } \\
\mathrm{n} \\
\text { Correl } \\
\text { ation } \\
\end{array}$ & , 197 & ${ }_{*}^{155^{5}}$ &, $085^{* *}$ & $188^{\text {** }}$ & 1 & $416^{* *}$ & , 214 & $321^{* *}$ &, $579^{* *}$ \\
\hline & $\begin{array}{l}\text { Sig. (2- } \\
\text { tailed) }\end{array}$ & 000 &, 000 & ,004 & ,000 & & , 000 &, 000 & 000 & 000 \\
\hline \multirow[t]{2}{*}{$\begin{array}{l}\text { Shopping and } \\
\text { leisure }\end{array}$} & $\begin{array}{c}\text { Pearso } \\
\mathrm{n} \\
\text { Correl } \\
\text { ation } \\
\end{array}$ & ${ }_{* *}^{171}$ & $179^{*}$ &, $114^{* *}$ & $155^{* *}$ & $416^{*}$ & 1 & 276 & $816^{* *}$ &, $735^{* *}$ \\
\hline & $\begin{array}{l}\text { Sig. (2- } \\
\text { tailed) }\end{array}$ & ,000 & ,000 & 000 & ,000 & 000 & & ,000 & ,000 & 000 \\
\hline \multirow[t]{2}{*}{ Special sites } & $\begin{array}{c}\text { Pearso } \\
\mathrm{n} \\
\text { Correl } \\
\text { ation } \\
\end{array}$ & ,334 & $219^{*}$ &, $139^{* *}$ &, $175^{* *}$ & $214^{* * 4}$ &, $276^{* *}$ & 1 &, $259^{* *}$ & $539^{* 4}$ \\
\hline & $\begin{array}{l}\text { Sig. (2- } \\
\text { tailed) }\end{array}$ &, 000 &, 000 & 000 & ,000 &, 000 & (000, & & ,000 & 000 \\
\hline Landmarks & $\begin{array}{c}\text { Pearso } \\
n \\
\text { Correl }\end{array}$ & ,226 & ${ }^{178^{\circ}}$ &, $128^{* *}$ &, $112^{* *}$ & $321^{* *}$ & $816^{* *}$ & 259 & 1 &, $700^{*+4}$ \\
\hline
\end{tabular}

\begin{tabular}{|c|c|c|c|c|c|c|c|c|c|c|}
\hline & ation & & & & & & & & & \\
\hline & $\begin{array}{l}\text { Sig. (2- } \\
\text { tailed) }\end{array}$ &, 000 & 000 & 000 & ,000 & ,000 & ,000 &, 000 & & 000 \\
\hline \multirow[t]{2}{*}{$\begin{array}{c}\text { overal_tour_guide_e } \\
\text { xpectations }\end{array}$} & $\begin{array}{c}\text { Pearso } \\
n \\
\text { Correl } \\
\text { ation }\end{array}$ & ,401 & $588^{*}$ &, $518^{* *}$ & $451^{* *}$ & $579^{*}$ &, $735^{*}$ & ,539 &, $700^{* *}$ & 1 \\
\hline & $\begin{array}{l}\text { Sig. (2- } \\
\text { tailed) }\end{array}$ & 000 & , 000, & ,000 & ,000 & ,000 & , 000 &, 000 & ,000 & \\
\hline
\end{tabular}

The analysis of bivariate intercorrelation found that there is a statistically significant relationship between the variables "information satisfaction", "information understanding" and "tour quality assessment" (Table 8). The obtained correlation coefficients are positive, which means that the increase in grades in one variable indicates an increase in grades in the other variable. Pearson correlation coefficient between tour quality scores and satisfaction with the information provided is 0.40 which indicates that it is a moderate correlation (correlation coefficients up to 0.20 -insignificant, from 0.20 to 0.40 -low, from 0.40 to 0.70 moderate correlation, from 0.70 to 0.90 high correlation and from 0.90 to 1.00 very high correlation), statistically significant at the significance level of 0.01 . The Pearson coefficient of correlation between the quality assessments of the tour and the degree of understanding of the information is 0.16 , which means that it is an insignificant correlation and the changes in 
the first do not cause changes in the second. Pearson coefficient of correlation between information comprehension and satisfaction with the total information is 0.72 , which means that it is a high degree of correlation and that the two variables are directly proportionally related to a statistical significance of 0.01 . The highest degree of correlation is between the variables "shopping activities and leisure" and "degree of understanding of information" and with a Pearson coefficient of 0.99 which means that it is a very high correlation with a positive sign and changes in one result in changes in the other with direct proportionality and statistical significance at the level of 0.01 . There is the greatest degree of correlation between the variables "Orientation" Because these are moments in the tour that are crucial for tourists in terms of orientation in space and time, they have the most impact on what seemed most important to them at the moment, and that is to can arrive on time at a specific location and find the waiting area. They were most sensitive and alert when it came to information related to "shopping and leisure" and "orientation in space related to group waiting places", but the satisfaction with that information is at the lowest level compared to the satisfaction with other types of information.

\section{Conclusion}

The tourist guides that were evaluated by the respondents proved to be relatively good and from that it can be concluded that although in Macedonia we can not talk about who knows what kind of organization of the guide service, still the guides are trying and improving day by day. Many of them are educated and read literature that helps them overcome their professional challenges, although there are some where there is an absence of consulted literature. Generally, Macedonian tour guides invest in their knowledge and strive to improve day by day. As a final conclusion from the presentation in this doctoral dissertation, it can be concluded that tour guides are one of the most important tourist laborers in a destination; they are the pillar around which romantic stories about the destination are developed. From their professional performance with a solid knowledge of culture and nature, tourists enthusiastically perceive the information and in a particularly vivid way experience the complete story of the place where they stay or simply visit it for half a day or a few hours. From a communication point of view, foreign languages are essential. It can be concluded that frequent visitors strive to have a higher scale of tolerance for certain irregularities as in the case of the Dutch and Polish visitors in Macedonia. Certain tourists, especially the ones who are new to the destination are very critical and with a very law scale of tolerance as in the case of the French and Malaysian visitors.

The tour guides need to follow certain procedures and routines in order to be able to deliver a proper service. Not every tourist is same as the previous one and therefore guides need to adjust to the conditions on the terrain. Honesty and fairplay are the most important prerogatives when we talk about issuing a perfect tour guiding service.

\section{References}

[1] Brodsky-Porges, E. (1981). The grand tour travel as an educational device 16001800. Annals of Tourism Research, 8(2), 171-186. doi:10.1016/01607383(81)90081-5

[2] Cohen, E. 1985 The Tourist Guide: The Origins, Structure and Dynamics of a Role. Annals of Tourism Research 12:

[3] Hilbert. C. 1969 The Grand Tour. New York: Putnam.

[4] Curtin, S. (2010). Managing the wildlife tourism experience: The importance of tour 


\section{leaders.}

[5] International Journal of Tourism Research, 12(3), 219-236.

[6] Green, R., \& Jones, D. N. (2010). Practices, Needs and Attitude of Bird-Watching Tourists in

[7] Australia. Gold Coast: CRC for Sustainable Tourism

[8] Jonasson, M., (2014) A barrier free guided tourism for people with on intellectual disability, Session 1 - Sustainability of Guided Tours

[9] Lambert. R. S.. ed. 1935 Grand Tour: A Journey in the Tracks of the Age of Aristocracy. London: Faber and Faber.

[10] McDonnell, I; The Role of the Tour Guide in Transferring Cultural Understanding; Working Paper No. 3; School of Leisure, Sport and Tourism, University of Technology, http://www.business.uts.edu.au/lst/downloads/WP03_McDonnell.pdf

Sidney;

[11] Naumov, K. Улогата и значењето на туристичкото водење за туризмот во Република Македонија, doctoral dissertation, University "St. Kliment Ohridski"Bitola, Faculty of Tourism and Hospitality-Ohrid, Republic of Macedonia

[12] Vukonic, B., Cavlek, N. (2001), Rethinking of Education and Training for Tourism, Graduate School of Economics \& Business, University of Zagreb

[13] Oxford 1933 Oxford English Dictionary, Vol. IV. Clarendon: Oxford. 